Edukids volume 16 (1) tahun 2019

EDUKIDS: Jurnal Pertumbuhan, Perkembangan, dan Pendidikan Anak Usia Dini

Jln. Dr. Setiabudhi No. 229 Kota Bandung 40154. e-mail: edukid@upi.edu website: http://ejournal.upi.edu/index.php/edukid

\title{
MENINGKATKAN KECERDASAN KINESTETIK ANAK USIA DINI MELALUI PEMBELAJARAN TARI KIJANG
}

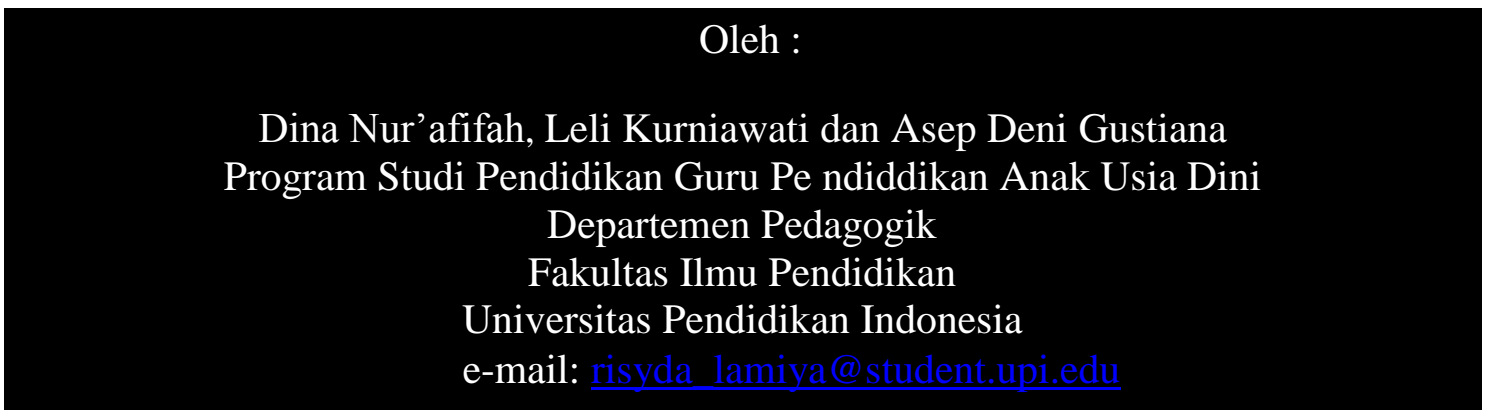

Abstrak: Penelitian dilatar belakangi belum berkembangnya kecerdasan kinetetik yang dimiliki anak di kelompok B TK Kemala Bhayangkari 18. Adapun solusi dalam mengatasi permasalahan tersebut yaitu menggunakan pembelajaran Tari Kijang sebagai stimulus gerak anak. Penelitian ini bertujuan untuk mengetahui peningkatan kecerdasan kinestetik anak setelah diterapkan pembelajaran Tari Kijang. Subjek pada penelitian ini berjumlah 15 anak yang terdiri dari 10 orang anak perempuan dan 5 orang anak laki-laki. Metode penelitian yang digunakan penelti yaitu penelitian tindakan kelas (PTK) dengan menggunakan model desain Kemmis dan Mc Taggart yang memiliki empat tahapan penelitian yang terdiri dari perencanaan, pelaksanaan, pengamatan dan refleksi. Instrumen penelitian yang digunakan berupa lembar observasi kecerdasan kinestetik anak (Checklist) dan catatan lapangan. Hasil penelitian terkait kecerdasan kinestetik anak pada siklus I menunjukan persentase sebesar 38\% dalam kategori berkembang sangat baik, sedangkan kecerdasan kinestetik anak pada siklus II menunjukan persentase sebesar $80 \%$ dalam kategori berkembang sesuai harapan. Hasil penelitian meunjukan bahwa pembelajaran Tari Kijang mampu meningkatkan kecerdasan kinestetik anak usia dini. Maka dari itu, dapat dijadikan sebuah rekomendasi bagi pendidik anak usia dini untuk menerapkan pembelajaran Tari Kijang sebagai salah satu alternatif kegiatan dalam meningkatkan kecerdasan kinestetik anak.

\section{Kata kunci: kecerdasan kinestetik, tari kijang}

Abstract: The research is based on the underdeveloped of students' kinaesthetic intelligence in group B of Kemala Bhayangkari 18 Kindergarten. The solutions to overcome these problems are using Kijang dance learning as a child's stimulus movement. This research aims to determine the improvement of children's kinaesthetic intelligence after the implementation of Kijang Dance. The subjects in this research were 15 children consisting of 10 girls and 5 boys. The research method used by the researcher was classroom action research (CAR) using a design model. Kemmis and Mc Taggart who have four stages of research consisting of planning, implementation, observation and reflection. The research instrument used was a kinaesthetic intelligence (Checklist) observation sheet and field notes for children. The results of the research related to children's kinaesthetic intelligence in the first cycle showed a percentage of $38 \%$ in the very good developing category, while the children's kinaesthetic intelligence in the second cycle showed a percentage of $80 \%$ is in the developing category as expected. The results of the reserach show that Kijang Dance learning is able to improve early childhood kinaesthetic intelligence. Therefore, it can be used as a recommendation 
for early childhood educators to apply Kijang dance learning as an alternative activity in improving children's kinaesthetic intelligence.

Keywords: kinaesthetic intelligence, kijang dance

\section{PENDAHULUAN}

Setiap individu tentu memiliki keunikan dan kecerdasannya masingmasing. Kecerdasan yang dimiliki akan berkembang jika dilatih secara terus menerus, termasuk anak usia dini. Pada usia golden age atau usia emas anak, mereka dapat mengembangkan kecerdasannya apabila diberikan stimulasi secara berkelanjutan dan terus menerus. Adapun konsep kecerdasan majemuk menurut Gardner dalam Armstrong (2013, hlm. 6-7) bahwa ada delapan macam kecerdasan yang dapat dikembangkan, salah satunya kecerdasan kinestetik. Pada penerapannya, berbagai kecerdasan tentunya memiliki pengaruh masing-masing, tergantung perlakuan yang digunakan saat menstimulasi seorang individu terkhusus anak usia dini. Begitu pun dengan kecerdasan kinestetik, saat menggunakan media yang merik dan disukai anak dalam memberikan stimulasi, harapannya anak mampu menerima lebih tangkap materi yang diberikan.

Kecerdasan kinestetik merupakan salah satu dari sembilan kecerdasan majemuk yang tentunya sangat penting untuk anak miliki, karena kecersdasan kinestetik merupakan suatu kecerdasan yang berhubungan dengan kemampuan dalam menggunakan tubuh secara terampil. Seelfeldt dan Wasik (2008, hlm: 95) mengemukakan bahwa "anak usia tiga, empat, dan lima tahun penuh dengan energi dan terus bergerak, waktu mereka tumbuh, keterampilan motorik kasar dan halus menjadi lebih cepat dan kemampuan mereka melakukan tugas yang menuntut keselarasan semakin baik". Selanjutnya salah satu karakteristik anak usia dini yaitu bergerak aktif, banyak yang beranggapan bahwa anak yang banyak bergerak merupakan anak yang memiliki kecerdasan kinestetik yang baik, maka akan sangat terlihat sekali perbedaannya saat ada anak yang memiliki hambatan pada kemampuan geraknya. Bimbingan guru sangat penting dalam menstimulasi anak mengembangkan kecerdasan kinestetik, tentunya dengan metode yang menarik bagi anak.

Dalam perkembangannya, anak yang memiliki kecerdasan kinstetik tinggi biasanya mereka lebih mahir jika dibandingkan dengan anak lain dalam bidang olahraga, keterampilan, dan berbagai aktivitas lain yang berhubungan dengan gerak tubuh. Diperkuat oleh pendapat Yusvarita (2009, vol.2) yang menyatakan bahwa "Kecerdasan kinestetik sangat penting untuk dikembangkan setiap anak, dengan penguasaan kecerdasan kinestetik anak dapat meningkatkan kemampuan psikomotorik, membangun rasa percaya diri, meningkatkan kemampuan sosial, meningkatkan kemampuan sportivitas, meningkatkan kesehatan tubuh". Semua hal tersebut tentunya memiliki pengaruh jangka panjang bagi anak usia dini bukan hanya pada masa kanak-kanak mereka, namun juga sangat berpengaruh besar bagi anak dalam menjalankan kehidupannya di masa yang akan datang.

Berdasarkan observasi pertama di TK tersebut pada tanggal 10 Januari 2019 peneliti menemukan beberapa permasalahan kemampuan gerak anak. Menurut informasi dari salah satu guru kelompok B dan hasil pengamatan penulis bahwa perkembangan kecerdasan kinestetik anak kelompok B dapat dikatakan masih kurang berkembang. Terbukti dengan ditemukannya sekitar 
70\% anak kelompok B yang masih terlihat kesulitan dalam mengembangkan gerakan dasar tubuhnya seperti saat melakukan gerakan melompat dan meloncat pada pembelajaran olahraga masih banyak anak yang terlihat kurang mampu menyeimbangkan tubuhnya sampai hampir terjatuh. Saat observasi kedua pada tanggal 23 Januari 2019 peneliti menemukan kembali permasalahan yang terjadi, dimana saat kegiatan senam sebagian besar dari seluruh anak kelompok B terlihat kurang mampu mengikuti gerakan dasar yang dicontohkan oleh gurunya seperti terjatuh ketika mengangkat satu kaki selama 5 detik, kurang seimbang ketika melompat ke arah kanan dan kiri, dan sebagainya.

Berdasarkan hasil wawancara dengan kepala sekolah TK diperoleh informasi bahwa guru disana lebih sering melakukan kegiatan pembelajaran dikelas dan jarang memberikan pembelajaran fisik pada anak. TK tersebut hanya melaksanakan kegiatan fisik satu kali dalam satu minggu, sehingga stimulus yang didapat anak pun dirasa kurang optimal. Dari permasalahan yang ditemukan, dapat ditarik kesimpulan sementara bahwa kegiatan pembelajaran di TK tersebut masih berpusat pada guru, dimana masih kurangnya kemampuan guru di TK tersebut dalam memilih variasi kegiatan pembelajaran yang efektif guna melatih keterampilan fisik anak yang tentunya berpengaruh terhadap kecerdasan kinestetik mereka.

Anak usia dini hendaknya diberikan pembelajaran yang menopang karakteristik mereka, seperti kita ketahui anak memiliki keaktifan lebih dalam bergerak. Kegiatan yang menarik dan membuat anak senang diharapkan dapat membuat proses berjalannya stimulasi akan menjadi semakin mudah. Kegiatan menari dirasa cocok digunakan guru guna memberikan stimulasi untuk anak bergerak, mengingat karekteristik anak yang masih memiliki energi lebih dari orang dewasa. Dirasa penting pula pada era modern ini untuk lebih memperkenalkan kebudayaan daerah kita yaitu kebudayaan sunda salah satunya kesenian tradisional sunda kepada anak usia dini, karena sekarang ini tidak sedikit Taman Kanak-kanak yang masih kurang menanamkan kepada anak didik untuk melestarikan budaya daerah kita.

Campbell dkk (2002, hlm: 7796) mengemukakan bahwa tujuan materi program dalam kurikulum yang dapat mengembangkan kecerdasan fisik antara lain "berbagai aktifitas fisik, berbagai jenis olah raga, modeling, dansa, menari, dan body language”. Oleh karena itu, menari dapat dijadikan salah satu media yang menarik untuk perkembangan fisik anak. Banyak jenis tarian tradisional yang dapat guru gunakan untuk dijadikan stimulasi gerak bagi anak seperti Tari Merak, Tari Domba Garut, Tari Cendrawasih, dan Tarian Ke Sawah. Dari berbagai tarian tersebut, peneliti bermaksud mencari jenis tarian tradisional lain yang memiliki peran serupa yaitu mengasah keterampilan gerak anak guna meningkatkan kecerdasan kinestetik mereka, yaitu dengan Tari Kijang. Tari Kijang merupakan sebuah tarian bertema binatang yang berasal dari daerah Jawa Barat yang pada awal tahun 2000an dipopulerkan oleh Ardjo. Adapun dalam hasil penelitian Supartha (1983) mengemukakan bahwa "Tari Kijang ini memiliki beberapa ciri khas yang membedakan dengan tari-tari lainnya. Ciri khas Tari Kijang yaitu gerak-gerak yang indah dan lincah menyimbolkan tingkah laku kijang".

Alasan dipilihnya Tari Kijang sebagai stimulus dalam meningkatkan kecerdasan kinestetik anak usia dini dikarenakan peneliti melihat bahwa unsur tarian yang ada dalam Tari Kijang ini mencakup beberapa unsur gerak dasar seperti melompat dengan kaki bergantian, berjalan cepat dan pelan, dan berlari-lari. 
Dirasa relevan dalam menstimulasi kemampuan gerak dasar anak sehingga harapannya kecerdasan kinestetik mereka dapat berkembang dengan optimal. Selain itu, belum ditemukan pada penelitian sebelumnya mengenai penggunaan Tari Kijang dari Jawa Barat dalam mengembangkan kecerdasan kinestetik anak.

Penelitian tentang kecerdasan kinestetetik anak usia dini sebelumnya pernah dilakukan oleh beberapa peneliti, seperti yang dilakukan oleh,Yuningsih (2015), Khasanah (2016) dan Purwati (2018). Beberapa penelitian tersebut dilakukan dengan tujuan mestimulasi kecerdasan kinestetetik anak usia dini. Pada penelitian Yuningsih (2015) pengembangan yang dilakukan yaitu menggunakan pembelajaran gerak dasar Tari Minang dari Sumatera Barat dengan menggunakan metode penelitian tindakan kelas (PTK). Selanjutnya, penelitian yang dilakukan Khasanah (2016) menggunakan Tari Tradisional Angguk dari Jawa Tengah, dengan menggunakan metode penelitian tindakan kelas (PTK). Lalu yang terakhir yaitu penelitian Purwati (2018) menggunakan Pembelajaran Tari Cendrawasih dari Papua dengan metode studi kasus. Sementara itu, berdasarkan permasalahan yang ditemukan peneliti di TK Bhayangkari 18, dilakukan penelitian yang bertujuan untuk mengkaji lebih lanjut permasalahan yang terfokus pada kecerdasan kinestetik anak dan hendak mengaplikasikannya melalui penelitian tindakan kelas, dengan judul : "Meningkatkan Kecerdasan Kinestetik Anak Usia Dini Melalui Pembelajaran Tari Kijang" yang akan diimplementasikan pada siswa kelompok B salah satu TK di kecamatan Cicalengka.

\section{METODE}

Metode penelitian yang digunakan adalah penelitian tindakan kelas (classroom action research). Menurut Kemmis,1988 (dalam Sanjaya, 2011, hlm.24) mengemukakan bahwa penelitian tindakan kelas merupakan suatu bentuk penelitian reflektif dan kolektif yang bertujuan untuk meningkatkan penalaran praktik sosial mereka. McNiff (dalam Arikunto, dkk, 2015, hlm. 106) menyatakan bahwa dasar dari pelaksanaan penelitian tindakan kelas itu adalah untuk perbaikan. Maka penelitian tindakan kelas ini digunakan sebagai suatu tindakan yang bertujuan untuk memperbaiki permasalahan kecerdasan kinestetik anak usia dini melalui pemberian tindakan pembelajaran Tari Kijang . Penelitian ini berbasis kolaboratif, artinya peneliti bekerjasama dengan guru kelas, dimana guru berperan sebagai instruktur atau pemberi tindakan selama proses pembelajaran dan peneliti berperan sebagai observer (pengamat).

Teknik pengumpulan data yang digunakan pada penelitian ini yaitu observasi dan dokumentasi. Schmuck, 1997 (Mertler, 2016) menyatakan bahwa observasi sebagai sarana pengumpulan data kualitatif, meliputi penyaksian secara cermat dan pencatatan secara sistematis. Selanjutnya Sugiyono (2019, hlm. 29) mengemukakan bahwa dokumentasi merupakan catatan peristiwa yang dapat berupa gambar, tulisan dan karya-karya yang dimiliki seseorang. Dalam hal ini dokumentasi diberikan dalam bentuk gambar, digunakan sebagai alat bantu penelitian meningkatkan kecerdasan kinestetik anak usia dini melalui pembelajaran tari kijang di TK tempat dilakukannya penelitian, dengan tujuan memberikan informasi bahwa penelitian ini benar adanya.

Lokasi penelitian yang digunakan adalah TK Kemala Bhayangkari 18 Cicalengka.

Subjek penelitiannya adalah siswa kelompok B TK Kemala Bhayangkari 18 dengan jumlah 15 anak, terdiri dari 10 anak perempuan dan 5 anak perempuan. 
Dalam penelitian ini instrumen yang digunakan merupakan daftar ceklis dan catatan lapangan.

Daftar ceklis adalah suatu daftar yang memuat item-item pernyataan tentang aspek-aspek yang mungkin muncul terjadi dalam suatu situasi, tingkahlaku, atau kegiatan individu yang diamati. Semua aspek tingkah laku, situasi yang akan diamati telah dinyatakan dalam suatu daftar. Sedangkan catatan lapangan catatan lapangan merupakan penjelasan secara naratif mengenai seluruh kegiatan anak selama proses pemberian tindakan.

Instrumen ini akan diberikan dan diisi oleh observer secara langsung di lapangan. Observer diminta untuk mengisi seluruh item pernyataan yang terdapat dalam instrumen dengan cara memilih salah satu alternatif jawaban dari tiga altenatif jawaban, yaitu: BB (Belum Berkembang), MB (Mulai Berkembang), BSH (Berkembang Sesuai Harapan), BSB (Berkembang Sangat Baik). Jawaban diberikan dengan cara memberi tanda ceklis $(\sqrt{ })$ pada salah satu kolom jawaban yang disediakan.

Data yang diperoleh dalam penelitiana ini akan dianalisis melalui kualitatif dan kuantitatif. Dalam proses analisis data, peneliti berlandaskan pada teori yang dikemukakan oleh Sugiyono (2009, hlm. 246) bahwa terdapat beberapa kegiatan yang dapat dilakukan dalam analisis data, yaitu reduksi data, pemaparan data dan penyimpulan.

\section{HASIL DAN PEMBAHASAN}

1. Profil Kecerdasan Kinestetik Anak Usia Dini Sebelum Diterapkan Pembelajaran Tari Kijang.

Hasil perolehan data pada saat observasi pemberian tindakan pra siklus ini dapat diperoleh hasil terkait profil kecerdasan kinestetik anak sebelum pelaksanaan tindakan pembelajaran Tari Kijang, yaitu sebagian besar anak belum mampu menguasai kecerdasan kinestetiknya dengan baik. Hal tersebut terlihat dari masih banyaka anak yang kesulitan mengikuti beberapa kegiatan fisik yang diberikan berlandaskan pada indikator kecerdasan kinestetik yang digunakan. Dari 15 anak yang mendapat tindakan pada pra siklus, terdapat 9 anak yang masih berada pada kategori belum berkembang (BB), yaitu KR, YS, SY, ZD, FK, AJ, AD, EL, dan AL. Selanjutnya terdapat 6 anak yang berada pada kategori mulai berkembang (MB), yaitu KY, AZ, NJ, FB, SL dan AY. Sedangkan belum terdapat anak yang mencapai kategori berkembang sesuai harapan (BSH) dan berkembang sangat baik (BSB). Adapun penjabaran dalam bentuk persentase, yakni dari 15 anak, yang termasuk pada kategori belum berkembang (BB) berjumlah 9 anak dengan persentase $60 \%$. Selanjutnya anak dalam kategori mulai berkembang (MB) berjumlah 4 anak dengan persentase $27 \%$, lalu anak dalam kategori berkembang sesuai harapan (BSH) berjumlah 2 anak dengan persentase $13 \%$. Sedangkan pada pra siklus ini tidak ada anak yang termasuk pada kategori berkembang sangat baik (BSB) dengan persentase 0\%. Dapat digambarkan melalui diagram berikut ini:

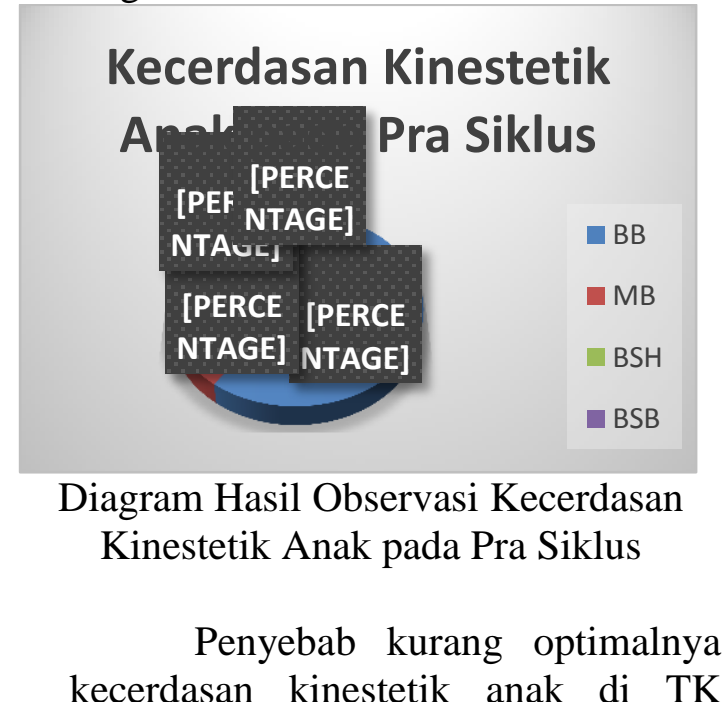


tersebut yakni karena jarangnya pemberian stimulasi gerak yang efektif, dimana kegiatan pembelajaran yang menyangkut keterampilan fisik hanya dilaksanakan sekali dalam seminggu. Padahal merupakan hal yang penting bagi anak usia dini untuk mengembangkan kecerdasan kinestetiknya. Hal ini sejalan dengan pendapat Sudjana (2008, hlm. 170174) bahwa tujuan kecerdasan kinestetik yaitu meningkatkan keampuan psiko-motor, meningkatkan keterampilan sosial, membangun rasa percaya diri dan harga diri, meletakan fondasi bagi gaya hidup sporty dan meningkatkan kesehatan.

2. Proses Penerapan Pembelajaran Tari Kijang dalam Meningkatkan Kecerdasan Kinestetik Anak Usia Dini.

Pada penelitian ini, pelaksanaan pemberian tindakan pembelajaran Tari Kijang dilakukan selama dua siklus. Dalam penelitian ini terdapat empat tahapan yang dilakukan, seperti pendapat Kemmis \& Mc Taggart (Yaumi \& Damopoli, 2014. Hlm. 24) bahwa dalam penelitian tindakan kelas meliputi empat tahap yaitu (1) Perencanaan, (2) Pelaksanaan, (3) Pengamatan (4) Refleksi. Penelitian ini dilaksanakan selama kurang lebih 3 minggu yaitu mulai dari tanggal 19 Maret - 11 April 2019. Selama pelaksanaan penelitian ini tema yang digunakan dalam kegiatan pembelajaran yaitu "Negaraku" denga sub tema "Tarian Tradisional Jawa Barat" dan topik "Tari Kijang".

Pelaksanaan Siklus I pertemuan I dilaksanakan pada hari Kamis, 28 Maret 2019. Pada pertemuan I di siklus I ini guru memulai dengan memberikan kegiatan pemanasan dengan metode Total Physical Response (TPR) kemudian guru pun mulai memberikan gambaran terkait Tari Kijang kepada anak, hal tersebut bertujuan agar anak mendapatkan pengetahuan mengenai kegiatan yang akan mereka lakukan. Selanjutnya Guru memperkenalkan gerakan Tari Kijang melalui tayangan video dan memperagakan beberapa ragam gerak Tari Kijang tanpa menggunakan iringan musik terlebih dahulu. Pemberian tindakan pembelajaran Tari Kijang ini disesuaikan dengan karakteristik serta kebutuhan anak. Hal ini selaras dengan pendapat Ardjo (2014, hlm. 28) bahwa guru perlu memperhatikan tahapan pembelajaran tari untuk anak diantaranya mengenalkan irama lagu, berikan bahan ajar secara bertahap, pengulangan dan penambahan, beri semangat dan tumbuhkan minat, serta harus kreatif.

Pelaksanaan siklus I pertemuan II dilaksanakan pada hari Senin,1 April 2019. Pada proses pemberian tindakan pembelajaran Tari Kijang ini, sebagian besar anak masih membutuhkan bantuan dari guru. Namun pada pertemuan II ini anak terlihat lebih antusias dan bersemangat dari pertemuan sebelumnya, karena guru memberikan contoh gerakan dengan menggunakan iringan musik Tari Kijang. Kemudian kegiatan pemanasan yang pada pertemuan I menggunakan metode TPR pun diganti dengan kegiatan lebih sederhana, karena tidak membuat anak terlalu kelelahan sebelum pembelajaran tari dimulai. Sehingga pembelajaran dirasa lebih efektif dibandingkan dengan pertemuan sebelumnya. Sejalan dengan pendapat Mulyani (2016, hlm. 109) bahwa diperlukan kecermatan bagi guru tari dalam penentuan materi pembelajaran tari yang baik dan sesuai agar tujuan pembelajaran sesuai dengan yang diharapkan. 
Pelaksanaan siklus II pertemuan I dilaksanakan pada hari Selasa, 9 April 2019. Pada petemuan ini anak-anak terlihat mulai menikmati kegiatan menari yang dilakukan. Anak bergerak dengan cukup luwes dan juga bersemangat. Selain itu beberapa anak juga yang mulai mampu menyesuaikan gerakan dengan irama musik, SL, KY, FB, SY, AD, NJ, EL, AZ dan FK sangat bersemangat dan memperlihatkan ekspresi yang gembira saat menari. Seperti pendapat Sekarningsih dan Rohyani (Mulyani, 2016, hlm. 26) bahwa tari merupakan komunikasi rasa yang disampaikan melalui gerak ritmis yang indah. Namun, belum semua anak mampu memperlihatkan hal tersebut, rata-rata anak masih kesulitan dalam beberapa gerakan yang menyangkut koordinasi dan keseimbangan seperti memutar badan 360 derajat di tempat, melompat sejauh satu meter ke arah depan mendarat dengan dua kaki dan melompat dengan satu kaki ke arah depan sebanyak 5 langkah.

$$
\text { Pelaksanaan siklus II }
$$

pertemuan II dilaksanakan pada hari Kamis, 11 April 2019. Pada siklus II ini sebagian besar anak sudah mampu mengikuti gerakan tari kijang dengan baik. Kemudian pada pertemuan II ini proses pembelajaran Tari Kijang sudah berlangsung secara optimal, meskipun masih ada permasalahan yang ditemukan, namun hal tersebut masih mampu teratasi.

$$
\text { Berdasarkan pelaksanaan }
$$
penelitian dan sumber diatas, dapat disimpulkan bahwa kecerdasan kinestetik anak dapat meningkat apabila diberikan stimulus secara berkelanjutan. Disamping itu, kecerdasan kinestetik anak juga harus harus terfasilitasi sesuai dengan kebutuhan anak. Maka dari itu, kegiatan pembelajaran yang diberikan kepada anak hendaknya dikemas sebaik dengan langsung melibatkan anak dalam setiap prosesnya. Selaras dengan pendapat Klobs (Abidin, 2009, hlm. 26) bahwa gaya belajar yang dapat meningkatkan kemampuan siswa salah satunya yaitu gaya Accomodator, yang berarti proses belajar anak akan lebih baik dengan mengalami dan melakukan langsung materi yang disampaikan. Dengan demikian pembelajaran Tari Kijang merupakan salah satu solusi dalam meningkatkan kecerdasan kinestetik anak usia dini.

3. Peningkatan Kecerdasan Kinestetik Anak Setelah Dilaksanakan Pembelajaran Tari Kijang.

Setelah peneliti melakukan penelitian di TK Kemala Bhayangkari 18 dengan menerapkan pembelajaran Tari Kijang, kecerdaan kinestetik anak mengalami peningkatan. Hal tersebut ditunjukan oleh berbagai peristiwa yang ditemukan dilapangan saat berlangsungnya tindakan dari mulai siklus I sampai dengan siklus II. Adapun peningkatan kecerdasan kinestetik anak pada siklus I dapat dilihat pada diagram berikut ini :

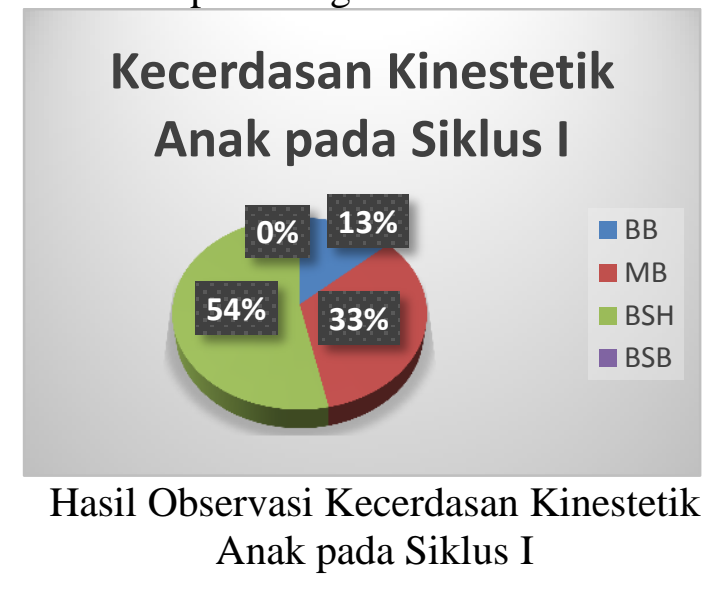

Berdasarkan diagram diatas, diperoleh data bahwa kecerdasan kinestetik anak di kelompok B TK Kemala Bhayangkari 18 dengan jumlah 15 anak, pada siklus I ini yang termasuk pada kategori belum berkembang (BB) berjumlah 2 anak 
dengan persentase $13 \%$. Selanjutnya, anak yang termasuk pada kategori mulai berkembang (MB) berjumlah 5 anak dengan persentase $33 \%$, lalu anak yang termasuk pada kategori berkembang sesuai harapan (BSH) berjumlah 8 anak dengan persentase $54 \%$. Sedangkan tidak terdapat anak yang berada dalam kategori berkembang sangat baik (BSB) dengan persentase $0 \%$.

Selanjutnya pada siklus II, kecerdasan kinestetik anak setelah diterapkannya pembelajaran Tari Kijang kembali mengalami peningkatan yang dapat dilihat dari diagram berikut ini :

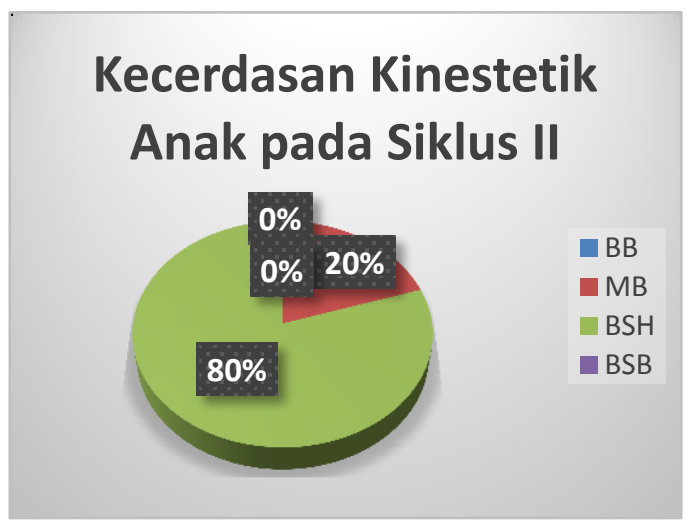

Hasil Observasi Kecerdasan Kinestetik Anak pada Siklus II

Berdasarkan diagram diatas, diperoleh data bahwa kecerdasan kinestetik anak di kelompok B TK Kemala Bhayangkari 18 yang berjumlah 15 anak, yang termasuk pada kategori belum berkembang (BB) berjumlah 0 anak dengan persentase $0 \%$. Selanjutnya, anak yang termasuk pada kategori mulai berkembang (MB) berjumlah 3 anak dengan persentase $20 \%$, lalu anak dalam kategori berkembang sesuai harapan (BSH) berjumlah 12 anak dengan persentase 80\%. Sedangkan pada siklus II ini, tidak terdapat anak yang berada pada kategori berkembang sangat baik (BSB), karena tidak ada anak yang perkembangannya melampaui nilai rata-rata dari indikator capaian.

Adapun peningkatan kecerdasan kinestetik anak pada setiap siklusnya dapat digambarkan melalui grafik seperti berikut ini :

\section{Kecerdasan Kinestetik Anak pada Setiap Siklus}

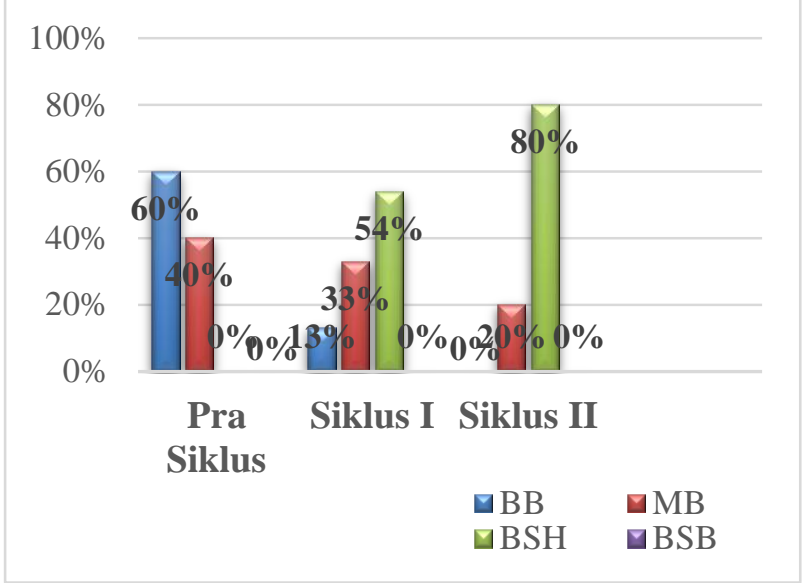

Berdasarkan grafik di atas, dapat disimpulkan bahwa kecerdasan kinestetik anak telah mengalami peningkatan. Hal tersebut ditunjukan dengan pencapaian kategori berkembang sesuai harapan (BSH) yang telah mencapai persentase $80 \%$ yang mana telah mencapai target indikator keberhasilan.

\section{SIMPULAN}

Berdasarkan hasil penelitian dengan judul meningkatkan kecerdasan kinestetik anak usia dini salah satu TK di kecamatan Cicalengka, diperoleh simpulan bahwa Tari Kijang selain mampu meningkatkan kecerdasan kinestetik, juga mampu menumbuhkan rasa percaya diri anak. Adapun simpulan yang berlandaskan pada pertanyaan penelitian yaitu dipaparkan sebagai berikut :

1. Kecerdasan kinestetik anak kelompok B di TK Kemala Bhayangkari 18 masih belum berkembang secara optimal. Hal tersebut terlihat dari hasil pengamatan yang dilakukan pada pra siklus, yaitu dari 15 anak terdapat 9 
anak yang kecerdasan kinetetiknya terlihat belum berkembang dengan optimal, terlihat mayoritas anak belum mampu mencapai indikator kecerdasan kinesteik. selanjutnya terdapat 5 anak sudah mulai mampu mengikuti stimulasi gerakan seperti melompat, meloncat, dan berputar, namun masih dengan bantuan guru. Kemudian terdapat 2 anak yang sudah mampu mencapai indikator kecerdasan knestetik dengan cukup baik tanpa diberikan bantuan oleh guru. Sedangkan tidak ada anak yang memiliki kemampuan diatas rata-rata yang mampu melampaui indikator capaian perkembangan kinestetik yang ada. Hal ini disebabkan oleh kurang variatifnya pembelajaran yang diberikan guru kelas pada setiap kegiatan pembelajaran. Sehingga anak kurang memperoleh stimulus berupa kegiatan fisik secara rutin, guna mengembangkan kecerdasan kinestetiknya.

2. Penerapan pembelajaran Tari Kijang memberikan dampak yang cukup baik terhadap kecerdasan kinestetik anak. Hal ini dapat dilihat dari hasil pengamatan pada siklus I hingga siklus II, terdapat peningkatan yang muncul secara bertahap. Pada saat pelaksanaan pembelajaran pada siklus II anak sudah mulai terlihat bersemangat dan leluasa dalam melakukan gerakan, karena Tari Kijang ini merupakan kegiatan baru yang belum pernah dilakukan sebelumnya.

3. Kecerdasan kinestetik anak mengalami peningkatan yang signifikan setelah diterapkannya pembelajaran Tari Kijang. Mayoritas anak sudah mampu memperagakan seluruh ragam gerak dengan baik, dapat dibuklikan dengan hasil penelitian yaitu terdapat 12 dari 15 anak sudah mampu berada pada kategori berkembang sesuai harapan
(BSH), dengan 3 anak yang masih berada pada kategori mulai berkembang (MB), dan sudah tidak ada anak yang berada pada kategori belum berkembang (BB).

Pada siklus II, peningkatan kecerdasan kinestetik anak melalui pembelajaran Tari Kijang dinyatakan telah melampaui target yang ditentukan. Maka dari itu dapat disimpulkan bahwa Tari Kijang mampu menjadi alternatif kegiatan dalam meningkatkan kecerdasan kinestetik anak.

\section{DAFTAR RUJUKAN}

Ardjo, I.D. (2008). Tari Sunda 19401965. Bandung: Pusbitari Press.

Ardjo, I.D. (2014). KAWIT (Teknik Gerak Dasar \& Tari Dasar Sunda). Bandung: Pusbitari Press.

Amstrong, T. (2013). Kecerdasan Multipel di Dalam Kelas Edisi Ke-3. Jakarta : Permata Puri Media.

Arikunto, S., dkk. (2015). Penelitian Tindakan Kelas Edisi Revisi. Jakarta : PT Bumi Aksara.

Arikunto, S. (2013). Manajemen Penelitian. Jakarta : PT Rineka Cipta.

Campbell, L. dkk. (2002). Multiple Intelegence Metode Terbaru Melesatkan Kecerdasan. Depok: Inisiasi Press.

Khasanah, I. (2016). Meningkatkan Kecerdasan Kinestetik Anak Usia Dini Melalui Tari Tradisional Angguk di TK Melati II. Glagah: Jurnal PAUD Edisi 3: 292-300.

Mertler, C.A. (2016). Action Research (Mengembangkan Sekolah dan 
Memberdayakan Guru). Yaumi, M. \& Damopoli, M. (2014).

Yogyakarta: Pustaka Pelajar.

Mulyani, N. (2016). Pendidikan Seni Tari Anak Usia Dini. Yogyakarta: Gava Media.

Sanjaya, W. (2011). Penelitian Tindakan Kelas. Jakarta : Kencana.

Sugiyono. (2009). Metode Penelitian Kuantitafif, Kualitatif, dan $R \& D$. Bandung: Alabeta.

Sudjana, N. (2008). Dasar-dasar Proses Belajar Mengajar. Bandung : Sinar Baru Algesindo. Action Research. Jakarta: Kencana Prenadamedia Group.

Yuningsih, R. (2015). Peningkatan Kecerdasan Kinestetik Melalui Pembelajaran Gerak Dasar Tari Minang. Jakarta: Jurnal Pendidikan Anak Usia Dini. Vol. 9. Edisi 2: 233-250.

Yusvarita. (2009). Peningkatan Kecerdasan Kinestetik Anak Melalui Tari Ke Sawah Di Taman Kanak-Kanak Toyibah Talawi. Padang: Jurnal PAUD. Vol. 1. No.1: 1-11. 